\title{
The Role of Belief in a Just World (BJW) in Learner Autonomy
}

\author{
Di Lan
}

\author{
Guangdong Baiyun University \\ 849319930@qq.com
}

\begin{abstract}
The current research seeks to explore how students' belief in a just world (BJW) is linked with learner autonomy. Convenient sampling technique is adopted, and 276 Chinese students from vocational college are surveyed. Results of regression analyse shows that BJW, especially BJW-general, is significantly predictive of learner autonomy. The results suggest that, students' perception of justice (BJW) may have influence on their autonomous learning. Informed by this results, educators and parents should work together to improve students' BJW.
\end{abstract}

Keywords: learner autonomy, belief in a just world, vocational students.

\section{INTRODUCTION}

Learner autonomy has been regarded as an ultimate goal of education for a long time [1] [3]. In present-day society, the the advancement of technology makes online resources more accessible than ever, which lays a solid basis for autonomous learning. However, the abundance of resources do not guarantee autonomous learning to take place, as it is the learners who determine whether the learning process should be initiated. Therefore, while learner autonomy can be approached from different perspectives (such as situational, cultural, and political), this research adopts a psychological perspective to probe the potential attributes. Researchers have associated learner autonomy with psychological traits that are apparently directed to it, such as motivation, self-efficacy, anxiety, etc [30]. However, little research has concerned indirect personal traits as variables. This research, therefore, seeks to shed a new light on this issue by associating learners' self-regulated learning with an indirect personal trait called belief in a just world (BJW).

\subsection{Learner autonomy}

The concept 'learner autonomy' had gained popularity in the field of education and psychology soon after it was put forward by Henri Holec in 1981. As stated by Holec [14], it is "the ability to take charge of one's own learning”. Later, Zimmerman [33] described self-regulated learners as participants who are metacognitively, motivationally, and behaviorally active in their own learning process. Learners themselves are also responsible for initiating, monitoring, and evaluating their learning process [22]. In addition, self-regulated learners should be willing to take charge of their learning process, while at the same time, they should have the capacity to take on responsibility that have traditionally belonged to teachers [7]. Benson [2] concludes that the capacity contains two cyclical components: "behavioral and (meta) cognitive".

Most of the relevant psychological studies in this field seek to explore variables that are directly connected to learners autonomy, such as volition, motivation, self-efficacy, and anxiety [30], paying little attention to personal traits that seem irrelevant to learner autonomy. Belief in justice world(BJW), a personal resource, has rarely been linked to learner autonomy.

\subsection{Belief in a just world" (BJW)}

The term "belief in a just world" (BJW) was first presented by Melvin Lerner in 1965. He described BJW as a basic human need, suggesting that people need to believe that they live in a just world where all people get what they deserve and deserve what they get [16] [17]. BJW is conceptualized as a positive illusion that encourages people to believe the world functions in an orderly, meaningful, and predictable way [18]. Lerner [19] proposes the concept "personal contract" in explaining the acquisition of BJW. He indicates that the growing children learned to postpone immediate desires for pleasure in order to acquire reward for long-term 
investments in the future. This "delay of gratification" [22] is an indispensable component in learner autonomy, as learners need to delay their immediate needs of pleasure and invest for long-term rewards.

Researchers had mainly focused on the nature of BJW until 1975, when Rubin and Peplau [24] [25] started measuring BJW with questionnaire, indicating BJW varied individually as a personal trait. The distinction between self and others was notably validated by Lipkusa et al. [20]. Dalbert [8] further develop the two spheres of BJW: the personal BJW and general BJW. The former reflects the belief that events in one's life are just, whereas the latter reflects the belief that the world is a just place. While the personal BJW is usually associated with life satisfaction [8] [27], perception of the meaning of life [4], general BJW is correlated with discrimination against disadvantaged groups [4] [27]. Generally speaking, although the two spheres of justice beliefs positively related to each other, they predict different indices of social attitudes and subjective well-being [28].

Early studies paid considerable attention to the negative influence of BJW, which is known as "blaming the victim" [26]. There is a large body of support for this phenomenon as people would derogate the disadvantaged groups (e.g. the unemployed, victims of AIDS, the elderly) in order to maintain their BJW when they feel they were unable to help with these situations [23] [4]. Only in recent years researchers' attention has been directed to the positive influence of BJW. Experimental studies prove that there is a positive relationship between BJW and well-being. Individuals high in BJW may feel less anxiety when facing stress [31], be more committed to the pursuit of long-term goals [13], be more likely to attribute their achievement results internally [11]. These inclinations are particularly associated with learner autonomy.

In the school context, specifically, data from different school studies confirm that BJW can serve as a resource, which not only protect students' mental health, but also promote their achievement behaviour [10]. However, studies that associate BJW with learner autonomy are lacking. Therefore, the current research seeks to explore the potential connection between BJW and learner autonomy.

\section{METHODS}

\subsection{Context and participants}

Based on a convenient sampling technique, a total of 276 college students (52 male students, 224 female students) from Guangdong China were invited to complete the questionnaire, among which 162 were freshman and 114 were sophomore. They were all from the same major.

\subsection{Research design and instrument}

\subsubsection{BJW}

BJW was measured in a Just World Scale [8], consisting of thirteen items that measure individuals' conviction of world justice in both general and personal term $($ Alpha $=0.88)$. Scales run from 0 (do not agree) to 5 (agree totally). The higher score students receive, the more they believe in justice.

\subsubsection{Learner autonomy}

Scale constructed by Zhuzude [34] was adopted in measuring learner autonomy. The scale contains two section, one measures learners' motivation in self-regulated learning (30 items, Alpha $=0.88$ ), the other measures learners ' strategies used in the learning process $(39$ items, Alpha $=0.93)$. Scales run from 0 (do not agree) to 5 (agree totally). The higher score students receive, the more they engage in autonomous learning.

\section{DATA COLLECTION AND ANALYSIS}

Students were invited to complete an online an questionnaire on their own digital devices without being told about the purpose of the study.

SPSS 23 was used to analyze the data. Firstly, the researcher performed a Pearson's Correlation analysis to examine whether the scores of students' BJW (self and general) are related to their score of learner autonomy. Second, the researcher applied regression analysis to analyze the predictive power of BJW (self and general) on learner autonomy.

\section{Results}

\subsection{Descriptive statistics}

Data compiled from 276 college students on the BJW-general, BJW-self and BJW total scores are shown in Table 1.

Table 1. Descriptive data of gender differences in BJW

\begin{tabular}{|l|l|r|r|r|}
\hline gender & BJW-general & BJW-self & BJW-total \\
\hline \multirow{5}{*}{ male } & $\mathrm{M}$ & 20.25 & 24.65 & 44.69 \\
\cline { 2 - 5 } & $\mathrm{N}$ & 52 & 52 & 52 \\
\cline { 2 - 5 } & $\mathrm{SD}$ & 4.067 & 4.067 & 6.864 \\
\hline \multirow{3}{*}{ female } & $\mathrm{M}$ & 21.44 & 25.24 & 46.68 \\
\cline { 2 - 5 } & $\mathrm{N}$ & 224 & 224 & 224 \\
\cline { 2 - 5 } & $\mathrm{SD}$ & 3.693 & 4.206 & 7.289 \\
\hline total & $\mathrm{M}$ & 21.22 & 25.13 & 46.30 \\
\cline { 2 - 5 } & $\mathrm{N}$ & 276 & 276 & 276 \\
\cline { 2 - 5 } & $\mathrm{SD}$ & 3.788 & 4.179 & 7.240 \\
\hline
\end{tabular}


Generally, students demonstrate stronger BJW-self (total $\mathrm{M}=25.13$ ) than $\mathrm{BJW}$-general (total $\mathrm{M}=21.22$ ). In addition, it is notable that female students show stronger belief that the world is just for them $(\mathrm{M}=25.24)$ and for other people $(M=21.44)$ than male students $(M=24.65$, $\mathrm{M}=20.25)$ do.

\subsection{Correlation analysis}

Table 2. Correlations between learner autonomy and BJW

\begin{tabular}{|c|c|c|c|c|}
\hline & $\begin{array}{c}\text { Learner autonomy } \\
\text { (motivation) }\end{array}$ & $\begin{array}{c}\text { Learner autonomy } \\
\text { (strategy) }\end{array}$ & BJW-self & BJW-general \\
\hline $\begin{array}{l}\text { Learner autonomy } \\
\text { (motivation) }\end{array}$ & 1 & & & \\
\hline Learner autonomy (strategy) & $.767 * *$ & 1 & & \\
\hline BJW-self & $.422 * *$ & $.460 * *$ & 1 & \\
\hline BJW-general & $.531 * *$ & $.563 * *$ & $.634 * *$ & 1 \\
\hline
\end{tabular}

**. ** correlation is significant at the 0.01 level(2-tailed).

As can be seen from Table 2 that students' BJW self and BJW general are significantly and positively related to learner autonomy motivation and learner autonomy strategies. In particular, a high positive correlation between learner autonomy motivation and learner autonomy strategies $(r=0.76, p<.001)$ is observed.

Results also show that BJW-general is more positively related to learner autonomy motivation $(\mathrm{r}=0.53$, ) and learner autonomy strategies $(\mathrm{r}=0.56$, $)$ than BJW-self do $(\mathrm{r}=0.42, ; \mathrm{r}=0.46)$.

\subsection{Regression analyses}

Table 3. Regression analysis for variable predicting learner

\begin{tabular}{|c|c|c|c|c|c|c|c|c|c|}
\hline \multirow[b]{2}{*}{ Model } & \multirow[b]{2}{*}{$\mathrm{R}$} & \multirow[b]{2}{*}{ R-squared } & \multirow[b]{2}{*}{$\begin{array}{l}\text { Adjusted } \\
\text { R-squared }\end{array}$} & \multirow[b]{2}{*}{$\begin{array}{l}\text { Errors in } \\
\text { standard } \\
\text { estimates }\end{array}$} & \multicolumn{5}{|c|}{ Change of statistics } \\
\hline & & & & & $\begin{array}{c}\text { Change } \\
\text { of } R\end{array}$ & $\begin{array}{c}\text { Change } \\
\text { of } F\end{array}$ & df1 & df2 & $\begin{array}{l}\text { Change of } F \\
\text { (significance) }\end{array}$ \\
\hline 1 & $.598^{\mathrm{a}}$ & 0.358 & 0.353 & 23.489 & 0.358 & 76.133 & 2 & 273 & 0 \\
\hline
\end{tabular}

Table 4. Model for variances predicting learner autonomy

\begin{tabular}{|c|c|c|c|c|c|c|c|c|c|}
\hline \multirow{2}{*}{ Model } & \multicolumn{2}{|c|}{$\begin{array}{l}\text { Nonstandard } \\
\text { Coefficient }\end{array}$} & \multirow{2}{*}{$\begin{array}{c}\begin{array}{c}\text { Standard } \\
\text { Coefficient }\end{array} \\
\beta\end{array}$} & \multirow{2}{*}{$\mathrm{t}$} & \multirow{2}{*}{ Sig. } & \multicolumn{3}{|c|}{ Correlation } & \multirow{2}{*}{$\begin{array}{c}\text { Collinearity } \\
\text { Statistics } \\
\text { VIF }\end{array}$} \\
\hline & B & $\begin{array}{l}\text { Standard } \\
\text { error }\end{array}$ & & & & $\begin{array}{l}\text { Zero } \\
\text { order }\end{array}$ & Segment & Units & \\
\hline (constant) & 152.611 & 9.235 & & 16.526 & 0 & & & & \\
\hline BJW-general & 3.673 & 0.484 & 0.476 & 7.595 & 0 & 0.584 & 0.418 & 0.368 & 1.672 \\
\hline BJW-self & 1.186 & 0.438 & 0.17 & 2.707 & 0.007 & 0.472 & 0.162 & 0.131 & 1.672 \\
\hline
\end{tabular}

Table 4 demonstrates that, in the model, both demonstrated as: $y=3.673 \times 1+1.186 \times 2+$ BJW-general $(\beta=.47, p<.01)$ and BJW-self $(\beta=.17$, $\mathrm{p}<.01)$ are statistically significant. Model that explains $59.8 \%$ of the variance indicates that BJW-general $(\beta=.47, \mathrm{p}<.01)$ and $\mathrm{BJW}$-self $(\beta=.17, \mathrm{p}<.01)$ are 152.611

The researcher also applied a T-test to explore whether gender should influence learners' BJW-general, BJW-self, and learner autonomy.

Table 5. Indicates that gender has an impact on BJW-general, but not on BJW-self and learner autonomy

\begin{tabular}{|c|c|c|c|c|c|c|c|c|c|c|}
\hline & & \multirow{2}{*}{$\mathrm{F}$} & \multirow{2}{*}{ sig } & \multirow{2}{*}{$\mathrm{t}$} & \multirow{2}{*}{$\frac{\text { Degrees }}{\text { freedom }}$} & \multirow{2}{*}{$\begin{array}{c}\text { Sig } \\
\text { (two-tailed) }\end{array}$} & \multirow{2}{*}{$\begin{array}{l}\text { Average } \\
\text { deviation }\end{array}$} & \multirow{2}{*}{$\begin{array}{l}\text { Standard } \\
\text { Error }\end{array}$} & \multicolumn{2}{|c|}{$\begin{array}{l}\text { 95\%Confidence } \\
\text { Interval }\end{array}$} \\
\hline & & & & & & & & & $\begin{array}{l}\text { upper } \\
\text { bound }\end{array}$ & $\begin{array}{l}\text { lower } \\
\text { bound }\end{array}$ \\
\hline BJW-general & $\begin{array}{l}\text { Homogeneity } \\
\text { of assumed } \\
\text { variance }\end{array}$ & 2.389 & 0.123 & -2.056 & 274 & 0.041 & -1.192 & 0.58 & -2.333 & -0.051 \\
\hline
\end{tabular}




\begin{tabular}{|c|c|c|c|c|c|c|c|c|c|c|}
\hline & $\begin{array}{l}\text { Homogeneity } \\
\text { of unassumed } \\
\text { variance }\end{array}$ & & & -1.936 & 71.785 & 0.057 & -1.192 & 0.616 & -2.419 & 0.035 \\
\hline \multirow{2}{*}{ BJW-self } & $\begin{array}{l}\text { Homogeneity } \\
\text { of assumed } \\
\text { variance }\end{array}$ & 0.089 & 0.766 & -0.906 & 274 & 0.366 & -0.583 & 0.643 & -1.85 & 0.684 \\
\hline & $\begin{array}{l}\text { Homogeneity } \\
\text { of unassumed } \\
\text { variance }\end{array}$ & & & -0.925 & 78.353 & 0.358 & -0.583 & 0.63 & -1.837 & 0.672 \\
\hline $\begin{array}{l}\text { Learner } \\
\text { autonomy }\end{array}$ & $\begin{array}{l}\text { Homogeneity } \\
\text { of assumed } \\
\text { variance }\end{array}$ & 0.006 & 0.939 & -1.419 & 274 & 0.157 & -6.367 & 4.488 & -15.203 & 2.468 \\
\hline & & & & \multicolumn{7}{|c|}{ T-test of same average deviation } \\
\hline & $\begin{array}{l}\text { Homogeneity } \\
\text { of unassumed } \\
\text { variance }\end{array}$ & & & -1.479 & 80.349 & 0.143 & -6.367 & 4.305 & -14.934 & 2.2 \\
\hline
\end{tabular}

\section{DISCUSSION}

The current study seeks to examine to what extent the BJW-general and BJW-self are associated with learner autonomy among Chinese vocational college students. One significant finding is that both BJW-general and BJW-self are predictive of learner autonomy. This finding, to some extent, is consistent with previous findings that prove BJW is positively correlated with elements that are significantly relevant to learner autonomy, such as motivation, investment in long-term goal, self-efficacy etc [13]. In addition, studies indicate that BJW is negatively correlated to negative feelings like distress level, which are also adverse to learner autonomy [6]. Generally, the results indicate that stronger believer of justice are more likely to engage in autonomous learning, both emotionally and behaviorally. Participants demonstrate stronger personal BJW than general BJW, which is in line with findings of previous research [8][9]. Surprisingly, it is BJW-general rather than $\mathrm{BJW}$-self that demonstrates stronger relation to learner autonomy. In other words, students value more, consciously or subconsciously, their general perception of justice than their personal experiences when they are to self-regulate their learning. This finding yields similar result as [10], which illustrates that students who show an adaptive level of achievement motivation are usually high in general BJW in school-specific context. This result sheds a new light on the importance of general BJW, as many studies tend to emphasize on personal BJW in predicting behavior in line with the justice motive [8] and overlook the functions of BJW general.

Since there are far more female participants than their male counterparts, the gender difference in this research should not be overlooked. The researcher ran a t-test to explore whether gender should affect BJW-self, BJW-general, and self autonomy. The result shows that gender has an impact on BJW-general, but not on BJW-self and learner autonomy. This is consistent with a number of studies that showing gender may affect BJW as a variable [15]. It is noticeable that females usually identify stronger BJW than males do in Chinese context; however, gender differences in BJW are less significant in western context, which may due to the variation of culture and tradition [5]. Future studies could explore the gender differences in BJW among different cultures.

\section{CONCLUSION}

This study set out to explore, among Chinese vocational college students, the relationship between BJW (both self and general) and learner autonomy. This resulted in two major findings. First, students' BJW (both BJW-self and BJW-general) could significantly predict learner autonomy. Second, learners' BJW-general is stronger predictor of learner autonomy than BJW-self does. These results offer insights into how researchers and educators should revalue BJW, especially BJW-general, as BJW not only serves as a resource that strengthens subjective well-being at school, but also a strong predictor of leaner autonomy.

As with any research, the current research also has limitations, which may offer possibilities for future research. First, among 276 participants, 224 were female students, and they were from the same major. Therefore, these results may not be representative of other college students. Second, the current research did not take students' family background into consideration. It is validated that students' socioeconomic status has an impact on their BJW [32], future studies may consider to measure and analyze this variable.

Nevertheless, this research makes an attempt to explore whether, or to what degree, Chinese students' BJW is associated with learner autonomy, examining the relationship between BJW and learner autonomy by a reliable questionnaire. Informed by the findings of the current research, it is expected that educators and parents should understand the importance of BJW, and joint forces to cultivate students' BJW. 


\section{REFERENCES}

[1] Benson, P., 2001. Teaching and researching autonomy in language learning. Harlow. England: Pearson Education.

[2] Benson, P., 2007. Autonomy in language teaching and learning. Language teaching, 40(1), pp.21-40.

[3] Benson, P., 2009. Making sense of autonomy in language learning. Maintaining control: Autonomy and language learning, pp.13-26.

[4] Bègue, L., \& Bastounis, M. (2003). Two spheres of belief in justice: Extensive support for the bidimensional model of belief in a just world. Journal of Personality, 71(3), 435-463.

[5] Bègue, L., Charmoillaux, M., Cochet, J., Cury, C. and De Suremain, F., 2008. Altruistic behavior and the bidimensional just world belief. The American journal of psychology, pp.47-56.

[6] Correia, I. and Dalbert, C., 2007. Belief in a just world, justice concerns, and well-being at Portuguese schools. European Journal of Psychology of Education, 22(4), pp.421-437.

[7] Dang, T.T., 2010. Learner autonomy in EFL studies in Vietnam: A discussion from sociocultural perspective. English Language Teaching, 3(2), pp.3-9.

[8] Dalbert, C., 1999. The world is more just for me than generally: About the personal belief in a just world scale's validity. Social justice research, 12(2), pp.79-98.

[9] Dalbert, C. and Stoeber, J., 2005. The belief in a just world and distress at school. Social Psychology of Education, 8(2), pp.123-135.

[10] Dalbert, C., \& Maes, J. (2002). Belief in a just world as a personal resource in school.

[11] Hafer, C.L. and Correy, B.L., 1999. Mediators of the relation between beliefs in a just world and emotional responses to negative outcomes. Social Justice Research, 12(3), pp.189-204.

[12] Hafer, C.L., 2000a. Do innocent victims threaten the belief in a just world? Evidence from a modified Stroop task. Journal of personality and social psychology, 79(2), p.165.

[13] Hafer, C.L., 2000b. Investment in long-term goals and commitment to just means drive the need to believe in a just world. Personality and Social Psychology Bulletin, 26(9), pp.1059-1073.

[14] Holec, H., 1979. Autonomy and foreign language learning, Council for Cultural Cooperation, Strasbourg (France).
[15] Huang.Z, 2019, The Impact of High School Students' Belief in A Just World on Academic Achievement : The Mediating Role of Self-regulated Learning.

[16] Lerner, M.J., 1965. Evaluation of performance as a function of performer's reward and attractiveness. Journal of personality and social psychology, 1(4), p.355.

[17] Lerner, M.J., 1970. The desire for justice and reactions to victims. Altruism and helping behavior, 205, p. 229.

[18] Lerner, M. J., \& Miller, D. T. . (1978). Just world research and the attribution process: looking back and ahead. Psychological Bulletin, 85(5), 1030-1051.

[19] Lerner, M.J., 1980. The Belief in a just world: A fundamental delusion. New York.

[20] Lipkusa, I.M., Dalbert, C. and Siegler, I.C., 1996. The importance of distinguishing the belief in a just world for self versus for others: Implications for psychological well-being. Personality and Social Psychology Bulletin, 22(7), pp.666-677.

[21] Little, D., 2002. Autonomy in language learning: Some theoretical and practical considerations. In Teaching modern languages (pp. 89-95). Routledge.

[22] Mischel, W., 1974. Processes in delay of gratification. In Advances in experimental social psychology (Vol. 7, pp. 249-292). Academic Press.

[23] Montada, L., 1998. Belief in a just world: A hybrid of justice motive and self-interest?. In Responses to victimizations and belief in a just world (pp. 217-246). Springer, Boston, MA.

[24] Rubin, Z. \& Peplau, L.A. (1973). Belief in a just world and reaction to another's lot: A study of participants in the national draft lottery. Journal of Social Issues, 29(4), 73-93.

[25] Rubin, Z. \& Peplau, L.A. (1975). Who believes in a just world? Journal of Social Issues,31(3), 65-89.

[26] Ryan, W. Blaming the victim. New York: Random House, 1971

[27] Sutton, R. M., \& Douglas, K. M. (2005). Justice for all, or just for me? More evidence of the importance of the self-other distinction in just-world beliefs. Personality and Individual Differences, 39(3), 637-645.

[28] Sutton, R. M., \& Winnard, E. J. (2007). Looking ahead through lenses of justice: The relevance of just-world beliefs to intentions and confidence in 
the future. British Journal of Social Psychology, 46(3), 649-666.

[29] Sutton, R. M., Douglas, K. M., Wilkin, K., Elder, T. J., Cole, J. M., \& Stathi, S. (2008). Justice for whom, exactly? Beliefs in justice for the self and various others. Personality and Social Psychology Bulletin, 34(4), 528-541.

[30] Thanasoulas, D., 2000. What is learner autonomy and how can it be fostered. The internet TESL journal, 6(11), pp.37-48.

[31] Tomaka, J. and Blascovich, J., 1994. Effects of justice beliefs on cognitive appraisal of and subjective physiological, and behavioral responses to potential stress. Journal of personality and social psychology, 67(4), p.732.

[32] Wu.J, 2021, Exploring medical interns' Belief in a just world and affecting factors.

[33] Zimmerman, B.J., 1986. Becoming a self-regulated learner: Which are the key subprocesses? Contemporary educational psychology, 11(4), pp.307-313.

[34] Zhu.Z, 2005, Scales of learner autonomy for college students. China academic journal electronic publishing house.

DOI:10.16187/j.cnki.issn1001-4918.2005.03.012 